az Egyesült Államokban - ahol nagyon elterjedtek a speech department-ek - sem sikerült különösebb megbecsülést, tiszteletet kivívnia az egyetemi közösségben. Körülbelül húsz éve azonban a helyzet megváltozni látszik."

Több mint negyven év telt el A retorika birodalma megjelenése - 1977 - óta. A könyv végén publikált bibliográfiát meg lehetne sokszorozni. Időközben az amerikaiak vaskos lexikonokat és összefoglalásokat publikáltak, a tübingeni retorikusok tető alá hozták a Historisches Wörterbuch der Rhetorik címü tizenkét kötetes retorikatörténeti összefoglalást, s egymás után jelentetik meg a Rhetorik-Forschungen köteteit, elötérbe helyezve a toposzkutatást. ADAMIK TAMÁS és tanítványai jóvoltából magyarul olvashatók már a négy nagy klasszikus retorikai múvei, megjelent a Retorikai lexikon, valamint a Régi-új retorika sorozat tizenhat kötete, tanulmányok sora. Megjelent első hazai retorikánk is magyar fordításban, PÉCSELI KIRÁLY IMRÉtől a Bevezetés a retorikába két könyvben. Mégis él még valamiféle gyanakvás a retorikával szemben, amelyet eloszlathat PERELMAN most már magyarul is olvasható, hiánypótló könyve.

\title{
Hivatkozott irodalom
}

ADAMIK TAMÁS 2004. A tudományos retorika és a filozófusok. In: Adamik Tamás - A. Jászó Anna Aczél Petra, Retorika. Osiris Kiadó, Budapest. 29-34.

ADAMIK TAMÁs föszerk. 2010, Retorikai lexikon. Kalligram Könyvkiadó, Pozsony.

BlumenBerg, HANS 1962. Paradigmen zu einer Metaphorologie. Bouvier, Bonn.

Golden, James L. - Berquist, Goodwin F. - Coleman, William E. eds. 1984. The Rhetoric of

Western Thought. Third Edition. Kendall - Hunt Publishing Company, Dubuque (Iowa).

KNAPE, JOACHIM 2000. Allgemeine Rhetorik. Reclam, Stuttgart.

Perelman, ChAÏM - OlBRECHTS-TyTECA, LuCIE 1958. La nouvelle rhétorique. Traité de l'argumentation. Presses Universitaires de France, Paris.

Perelman, Chaïm - Olbrechts-Tyteca, Lucie 1969. The New Rhetoric. A Treatise on Argumentation. University of Notre Dame Press, Notre Dame - London.

PERELMAN, CHAÏM 1977/2008. L'empire rhétorique. Rhétorique et argumentation. Vrin, Paris.

RAÁTZ JUDIT - TÓTHFALUSSY ZsóFIA szerk. 2011. A filozófia és a szónoki beszéd. Régi-új retorika sorozat 10. Trezor Kiadó, Budapest.

A. JÁSZÓ ANNA

ELTE Eötvös Loránd Tudományegyetem

\section{KÜL L̈NFÉLÉK}

\section{LexikoNet 2017}

\section{Diatopikus német tájszótármúhelyek találkozója}

2017. november 9. és 11. között Bécsben, az Osztrák Tudományos Akadémia szervezésében került sor a német nyelvü országok, valamint a német mint kisebbségi nyelvet használó országok diatopikus tájszótár-mühelyeinek ötödik találkozójára, amely a német nyelvü tájszótár-szerkesztés legrangosabb nemzetközi szakmai fóruma.

DOI: 10.18349/MagyarNyelv.2018.2.245 
A konferenciával egybekötött mühelytalálkozó célja összetett: fórumot ad a lezárt szerkesztési munkálatok (sorozatok, kötetek, tájszótárprojektek) bemutatásához és a még folyamatban lévő tájszótárszerkesztés nyitott kérdéseinek szakmai megvitatásához, betekintést nyújt a nagy német tájszótárak perifériáinak (pl. adatbank), makro- és mikrostruktúráinak digitális megjelenítési lehetőségeibe és gyakorlatába, valamint nemzetközi kapcsolatrendszert és szakmai beágyazottságot kínál a csatlakozó tájszótármühelyeknek.

A résztvevőket Alexandra N. Lenz, a Bécsi Egyetem Germanisztikai Intézetének professzor asszonya, a Variation und Wandel des Deutschen in Österreich (Variáció és változás a német nyelv osztrák változatában) az osztrák tudományos akadémiai kutatási projekt vezetője és az Osztrák-Bajor Tájszótár munkatársai, Philipp Stöckle és Andreas Gellan köszöntötte. A háromnapos konferencia programjában a nagy német tájszótárak prezentációit tematikus kerekasztal-beszélgetések követték, amelyek a különböző típusú szótárak szócikkszerkezeteit, a szerkesztőségek klasszikus és digitális eszköztárát, az adatbankok menedzselését, és a szótárprojektek összekapcsolódásának lehetőségeit tárgyalták.

Az elöadók a bajor, bajor-sváb, alemann, frank, hesseni, westfáliai és a magyarországi német nyelvjárások szókészletének lexikográfiai feldolgozottságával kapcsolatban a német nyelvterület nagy tájszótárműhelyeinek munkálatairól, eredményeiről és perspektíváiról számoltak be.

A nagy múltú Osztrák-Bajor Tájszótár (Wörterbuch der bairischen Mundarten in Österreich) 2015-ig az Ezzes címszóig publikálta anyagát. A több mint 3,6 millió lexikális egységet tartalmazó katalógus digitalizálása 1993-ban kezdődött. 2016 óta racionalizálták és újratervezték a lemmatizálandó egységek listáját, a mikrostruktúra információs kategóriáit, valamint konszolidálták az adatbankban archivált adatokat és keresési lehetőségeket. Az így módosított adatbank nem csak nyomtatott formátumú, hanem webalapú szócikkek szerkesztését is lehetővé teszi. A következő évek céljai közé tartozik az F és G betük címszavainak és szócikkeinek kidolgozása, a főkatalógus céduláinak digitalizálása és más projektek (Österreichische Dialektkartographie 1924-1956, Deutsch in Österreich) adatbankjaival való összekapcsolása.

A Bajor Tudományos Akadémiához tartozó müncheni székhelyü Bajor tájszótár (Bayerisches Wörterbuch) nyelvjárási adatainak egy jelentős része papíralapú katalóguscédulákon, illetve kérdőíveken található. A gyorsabb feldolgozás érdekében a kérdőíveket a közelmúltban beszkennelték és megfelelő identifikációs rövidítésekkel (kérdőív száma, helyszíne, közig. egysége) látták el. A beszkennelt kérdőíveket kérdések szerint digitálisan feldarabolták, így a 108.000 kérdöív alapján kb. 6,5 millió lexikális egységet kaptak, amelyeket a LexHelfer szerkesztői program szortírozza. A www.bwb.badw.de honlap átfogó tájékoztatást nyújt a Bajor tájszótár alapját képező nyelvjárásokról, a szótár felépítéséről, a források jellemzőiről, a kérdőívek tartalmáról, és többek között a szótárprojekt kezdeményezőiről, EBERHARD KRANZMAYER és BRUNO SCHWEIZER nyelvföldrajzi munkásságáról is.

Az észak-bajorországi Frank tájszótár (Fränkisches Wörterbuch) adatgyüjtési területe közigazgatásilag adott: az Ober-, Unter- és Mittelfranken (Felső-, Alsó- és Középfrank) területén beszélt keleti-frank, hesseni, thüringiai, sváb és bajor nyelvjárásokat 1913-tól dokumentálja. Az adatbankban 800.000 nyelvjárási adat található, amelyek szótő, jelentés, grammatikai jellemzők, szövegkörnyezet, transzkripció, adatgyüjtési hely, adatgyüjtői kommentár, szerkesztő kommentár, kérdőív és kérdés alapján kereshető.

A közép-németországi Hessen-Nassaui tájszótár(Hessen-Nassauisches Wörterbuch), amely túlnyomórészt az észak-, közép- és kelet-hesseni nyelvjárásokat fogja át, jelenleg 
46 füzetnyi (L-Z, A bizonyos részei) publikált szócikkel rendelkezik. A kész szócikkek digitalizált fakszimile formájában a https://www.lagis-hessen.de honlapon érhetők el. Ugyanitt a hesseni tájszótárban már lemmatizált, de szócikkel még nem rendelkező nyelvjárási szavak kereshetők nem csak a hesseni, hanem a délhesseni, rajnai, thüringiai és frankfurti szótárak lemmalistájában is.

A Magyarországi német tájszótár (Wörterbuch der Ungarndeutschen Mundarten) nyelvszigethelyzetben lévő, Magyarországon beszélt közép- és felnémet nyelvjárásokat dolgoz fel primer szinkrón profillal. A nyelvjárási adatok digitalizálása 2010-ben kezdődött, az adatbankban jelenleg 13.000 nyelvjárási adat található. A 700 próbaszócikken alkalmazott mikrostruktúra-koncepció figyelembe veszi az adatolt nyelvjárások tipológiai sokszínüségét, ezen kívül a címszavak jelentéseihez szociokulturális kommentárokat kapcsol.

A Svájci idiotikon (Schweizerisches Idiotikon), amelynek korpusza a késő középkortól a 21. századig terjed, a szó szoros értelmében véve nem klasszikus tájszótár, keletkezési körülményeinek és az akkori szótárkészítés céljainak megfelelően sokkal inkább történelmi-etimológiai szótárnak tekinthető. 16 kész kötete 159.000 címszót tartalmaz. A szótári munkálatokat várhatóan 10 éven belül befejezik. A nyomtatott formában publikált szótár retrodigitalizálása több részből tevődik össze: egyrészt a már megjelent kötetek oldalankénti digitalizálását, másrészt elektronikus hozzáférési lehetőségek kialakítását foglalja magába (lemmalista, köznyelvi lista, nyelvtani és szemantikai regiszter, teljes szöveg keresése szempontjából). A szótár honlapján (https://www.idiotikon.ch/) a teljes digitalizált fakszimile megtalálható, sok más érdekesség, pl. szófejtések, hangklippek mellett. A honlap naplózza a látogatók által keresett lemmákat, így a szerkesztők viszszajelzést kapnak arról, hogy mely szavakra milyen időintervallumban hány alkalommal kerestek rá a szótárhasználók és érdeklődők az idiotikon elektronikus verziójában.

A Westfáliai tájszótár (Westfälisches Wörterbuch) az északnyugat-németországi Westfália alnémet nyelvjárásait 1969 óta archiválja, jelenleg a 3. kötetnél tart (H-L). A kilencvenes évek koncepcionális és infrastrukturális racionalizálása után átalakult a szerkesztési folyamat, amelynek következtében a 3. kötetet négy éven belül sikerült befejezni. A 4. és a záró 5. kötet szerkesztési munkálatai elöreláthatóan 2020-ig fognak folytatódni.

A Bajor-Sváb tájszótár (Dialektwörterbuch von Bayerisch-Schwaben) Bajorország délnyugati területén található Schwaben közigazgatási egységének szinkrón nyelvjárási adatait tartalmazza. Adatbankjában 36.500 lemmához tartozó nyelvjárási adat található, amelyekből kb. 3.000 címszót publikáltak eddig nyomtatott formában. A tájszótárt 2017től befogadta a müncheni Bajor Tudományos Akadémia, így a publikáció folytatódik, és a szócikkek a közeljövőben, digitális formában is elérhetővé válnak.

A konferencia zárszavában Alexandra N. Lenz és Philipp Stöckle összefoglalták a bemutatók és tematikus viták eredményeit és nóvumait, és kiemelték annak fontosságát, hogy a német tájszótárkészítés nemzetközi hálózatának kiépítése mind a szúk szakmai, mind a nemzetközi tájszótárkészítés számára elméleti és gyakorlati ismeretek bővülésével, szakmai elönyök biztosításával jár együtt.

A következő LexikoNet konferenciára 2018 novemberében Gießenben kerül sor.

KNIPF ERZSÉBET - MÜLLER MÁRTA ELTE Eötvös Loránd Tudományegyetem 